\title{
Qualitative Evidence for Expression of Klebsiella pneumoniae nif in Pseudomonas putida
}

\author{
By JOHN R. POSTGATE* AND HELEN M. KENT \\ AFRC Unit of Nitrogen Fixation, University of Sussex, Brighton BNI 9RQ, UK
}

(Received 23 March 1987; revised 14 May 1987)

\begin{abstract}
Pseudomonas putida MT20-3 carrying the Klebsiella pneumoniae nif plasmids pRD1 or pMF250 showed highly $\mathrm{O}_{2}$-sensitive aerobic acetylene reduction on low-N pyruvate or glucose agar. This finding confirms unequivocally that $K$. pneumoniae nif can be expressed in an obligate aerobe.
\end{abstract}

\section{INTRODUCTION}

The ability of members of the genus Pseudomonas to fix nitrogen, long subject to uncertainty (see discussion by Postgate et al., 1987), was finally established by the report (Barraquio et al., 1986) of $\mathrm{O}_{2}$-sensitive diazotrophy in $P$. saccharophila. The ability of genetic constructs of Pseudomonas to express the nif gene cluster of Klebsiella pneumoniae has also been doubted. Mergeay \& Gerits (1978) obtained transconjugants of a putative $P$. fluorescens carrying IncP or IncF plasmids bearing the $K$. pneumoniae nif cluster which reduced acetylene aerobically in stagnant culture. Their report had disquieting features because $(a)$ the Pseudomonas had originally been isolated as a Rhizobium and $(b)$ the IncF plasmid FN68, which is usually unstable, was accepted and expressed in this organism. Lehtinen \& Mäntsälä (1981) found that the more stable IncP $K$. pneumoniae nif plasmid pRD1 was unstable in $P$. fluorescens but obtained three strains of $P$. putida(pRD1) which, however, did not reduce acetylene in anaerobic or aerobic conditions. They did not state the precise nature of their 'aerobic' conditions but they confirmed the presence of $\mathrm{pRD} 1$ in their derivatives by mating $P$. putida(pRD1) to Escherichia coli and demonstrating nitrogenase synthesis in the recipients. The question is important because, with the withdrawal of a claim that these genes are expressed in nif mutants of Azotobacter vinelandii (Cannon \& Postgate, 1983), there is no clear evidence for their expression in an obligately aerobic host.

We now report unequivocal acetylene reduction by $P$. putida carrying plasmid-borne $K$. pneumoniae nif. The process is extremely $\mathrm{O}_{2}$-sensitive in $P$. putida and satisfactory quantitative data are not available. This finding was briefly mentioned by Postgate et al. (1987).

\section{METHODS}

Organisms and culture. Organisms and plasmids are listed in Table 1. P. putida MT20-3 (Williams \& Worsey, 1976) is a his derivative of $P$. putida WW20 which was cured of its Tol plasmid pWW20. The nif plasmid pMF250 is a descendant of RP4 via pRD1 (= RP41; Dixon et al., 1976) and pMF100 (Merrick et al., 1980) with the original drug resistance genes deleted and $\mathrm{Km}^{\mathrm{r}}$ restored with $\mathrm{Tn} 5$. Plasmids were normally resident in E. coli JC5466 except for pWW20 which is naturally resident in $P$. putida MT20 and its derivatives. Bacteria were grown aerobically at $29^{\circ} \mathrm{C}$ on minimal glucose agar (Davis \& Mingioli, 1950) with $30 \mu \mathrm{g}$ tryptophan $\mathrm{ml}^{-1}$ for $E$. coli JC5466 (pMF250) or $30 \mu \mathrm{g}$ histidine $\mathrm{ml}^{-1}$ for $P$. putida MT20-3. E. coli was sometimes grown at $37^{\circ} \mathrm{C} ; P$. putida MT20-3 did not grow at $37^{\circ} \mathrm{C}$. For mating, loops of donor $E$. coli and recipient $P$. putida were spread with 1 or 2 drops of saline phosphate buffer (SP; Krishnapillai \& Postgate, 1980) on Luria's agar (LA; Kennedy, 1977) and incubated for 18 to $24 \mathrm{~h}$ at $29^{\circ} \mathrm{C}$. Cells resuspended in SP were spread on glucose minimal agar with $15 \mu \mathrm{g}$ kanamycin $\mathrm{ml}^{-1}$. To enable transfer of IncQ plasmids to $P$. putida, donor $E$. coli JC5466 derivatives were 
Table 1. Bacteria and plasmids

Bacterial strains

Pseudomonas putida MT20-3 his

Escherichia coli JC5466

Plasmids

pWW20

pRD1

pMF250

pCK1

pRK2013

pMD45

pMM22
Genotype

Origin or reference

his trp recA rplE

Tol

Cb Km Tc Gnd Nif His ShiA Tra IncP

$\mathrm{Km}$ Gnd His ShiA Tra IncP

Sm Mob Km : nif $A$ : Km IncQ

Sm Tra

Sm Mob Km:ntrC:Km IncQ

Sm Mob Km:ntrA:Km IncQ
P. A. Williams, University of Bangor, UK

N. Willets

P. A. Williams

Dixon et al. (1976)

M. Filser, see Postgate \& Kent (1985)

Kennedy \& Robson (1983)

Figurski \& Helinski (1979)

Kennedy \& Drummond (1985)

M. Merrick, University of Sussex, UK

constructed carrying both the IncQ plasmid and the $\mathrm{Tra}^{+}$mobilizing plasmid pRK2013 (Figurski \& Helinski, 1979). Presumptive transconjugant Pseudomonas isolates, selected with $100 \mu \mathrm{g}$ streptomycin $\mathrm{ml}^{-1}$, were checked for absence of donor by their failure to grow on LA at $37^{\circ} \mathrm{C}$. Plasmids in transconjugants were demonstrated by electrophoresis of alkaline lysates or boiled SDS extracts in agarose gels (Cannon, 1980) as appropriate; plasmid pWW20 was detected by Wheatcroft \& Williams's (1981) method. Genetic evidence that the IncP plasmids retained relevant Klebsiella DNA in the new background was obtained by transconjugation from the $P$. putida derivatives to $E$. coli JC5466. Donor and recipient strains were mated in liquid NFDM (Cannon et al., 1974) supplemented with aspartate $\left(100 \mu \mathrm{g} \mathrm{ml}^{-1}\right)$ and Oxoid nutrient broth (NB; $2.5 \%$, w/v) (Postgate \& Kent, 1985) for $24 \mathrm{~h}$ at $30^{\circ} \mathrm{C}$, the culture selected for $\mathrm{Km}^{\mathrm{r}} \mathrm{Spc}^{\mathrm{r}} \mathrm{E}$. coli transconjugants and their $\mathrm{Nif}^{+}$phenotype checked by acetylene reduction in similar NFDM $+30 \mu \mathrm{g}$ tryptophan $\mathrm{ml}^{-1}$.

\section{RESULTS}

Plasmids pMF250 or pRD1 transferred from E. coli JC5466 to P. putida MT20-3 at about $3 \times 10^{-4}$ transconjugants per total cell population mated with $100 \%$ co-transfer of $\mathrm{Km}^{\mathrm{r}}$ and $\mathrm{His}^{+}$.

Slopes of $P$. putida(pRD1) or (pMF250) on glucose- or sodium pyruvate-based NFDM containing aspartate and NB, set with agar, were incubated in air until grown (18 to $24 \mathrm{~h}$ at $29^{\circ} \mathrm{C}$ ) and then sealed under $\mathrm{N}_{2}$ with low $\mathrm{O}_{2}$ (below). The cells grew as a thin film; they were clearly $\mathrm{O}_{2}$-limited because growth was more abundant in air. Such cultures gave clear and qualitatively reproducible acetylene reduction after 2 to $5 \mathrm{~d}$. All positive tubes were checked for absence of donor (see Methods); controls with wild-type $P$. putida were uniformly negative. A variety of formulations of the agar media was tested and, though the majority supported acetylene reduction, scatter between replicate tubes rendered the results quantitatively unsatisfactory. We concluded that glucose, pyruvate, succinate, citrate, acetate and mixtures thereof as carbon sources showed no consistent differences (except that acetate was not utilized by this strain at all) but that pyruvate was marginally the most consistently effective substrate. Aspartate and NB were desirable for derepression but increased concentrations were of no advantage, nor were addition of $10 \%(\mathrm{v} / \mathrm{v})$ nutrient agar (Oxoid) or $10 \%$ LA. Activity was obtained at $\mathrm{pO}_{2}$ values of 0.001 to 0.004 atm but no higher. This is a high level of $\mathrm{O}_{2}$ sensitivity; for example, the obligately anaerobic diazotroph $K$. pneumoniae M5al, tested on the agar medium in Fig. 1, showed only $60 \%$ inhibition of its anaerobic acetylene reduction rate under 0.2 atm $\mathrm{O}_{2}$.

In an effort to obtain standardized quantitative replication, the procedure and conditions given in Fig. 1 were adopted for routine use but an unacceptable scatter of reduction rates and lags occurred among triplicate tubes. We attribute this scatter partly to inhomogeneity of bacterial growth on the agar, partly to imperfect replication of oxygen tensions in the system used. However, in no test did P. putida(pMF250) or (pRD1) reduce acetylene if sealed under pure $\mathrm{O}_{2}$-free $\mathrm{N}_{2}$, nor if $\mathrm{NH}_{4} \mathrm{Cl}(0 \cdot 2 \%$, w/v) were present in the agar. No anaerobic growth of this strain occurred with nitrate or fumarate as electron acceptors for glucose, pyruvate or fumarate. 


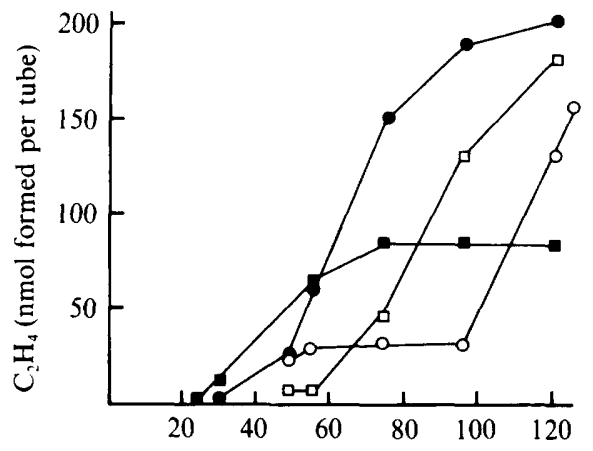

Time (h) at $29^{\circ} \mathrm{C}$ after injection of $\mathrm{C}_{2} \mathrm{H}_{4}$

Fig. 1. Acetylene reduction on low-N agar slopes at low $\mathrm{pO}_{2}$ by $P$. putida MT20-3(pMF250) and derivatives. Organisms from $24 \mathrm{~h}$ plates of glucose minimal medium were suspended to similar densities $\left(\mathrm{OD}_{540}\right.$ about 0.5$)$ and inoculated in triplicate with a loop on $10 \mathrm{ml}$ pyruvate-NFDM agar slopes in $30 \mathrm{ml}$ tubes with kanamycin or kanamycin and streptomycin, as appropriate. After $7 \mathrm{~h} \mathrm{at}$ $29^{\circ} \mathrm{C}$ in air, tubes were tilted carefully to wet the whole agar surface. After $24 \mathrm{~h}$ in air, all tubes were gassed out aseptically with $\mathrm{N}_{2}$, sealed with a Suba-seal closure and air injected to $0.004 \mathrm{~atm} \mathrm{O}_{2}$. After a further $21 \mathrm{~h}$ (time zero in the Figure), $1 \mathrm{ml} \mathrm{C}_{2} \mathrm{H}_{2}$ was injected. Selected tubes are illustrated of constructs carrying the nif plasmid pMF250 alone $(O)$ or with pCK1 ( $\square$ ), pMD45 ( $\square$ ) or pMM22 (O) (see text and Table 1). Lags, turnover points and reduction rates were not consistent among triplicate tubes of the strains tested but all were qualitatively positive.

Constructs of $P$. putida(pMF250) were made carrying the plasmids pCK1 (nif $A^{c}:$ Kennedy \& Robson, 1983), pMD45 (ntr $C^{\mathrm{c}}$ : Kennedy \& Drummond, 1985) and pMM22 (ntrA $A^{\mathrm{c}}:$ M. Merrick, personal communication). None appeared better or worse than the parent (Fig. 1). The bacterial growth washed off six slopes, which had given clear, continuous acetylene reduction, into SP was assayed for protein by the Lowry method and specific activities were calculated. They were similar at about $0.3 \mathrm{nmol} \mathrm{C}{ }_{2} \mathrm{H}_{4}$ formed (mg protein) ${ }^{-1} \mathrm{~min}^{-1}$ (cf. 70 to 180 for $K$. pneumoniae) but for one capricious tube of substantially higher activity which gave ordinary activity on subculture.

The Tol plasmid pWW20 carries the $x y l R$ gene which regulates the $x y l A B C$ cluster. It does so via a promoter (OP1) which shows considerable homology to Ntr-activatable promoters of nif and other operons (see Dixon, 1986). However, slopes of $P$. putida MT20-3(pWW20, pMF250) showed no significant differences in acetylene-reducing activity from slopes of $P$. putida (pMF250). Induction of $x y l R$ by including methylbenzyl alcohol in the medium decreased rather than augmented activity.

$\mathrm{O}_{2}$-sensitive aerobic acetylene reduction by $P$. putida(pMF250) growing dispersed in sloppy NFDM agar was mentioned by Postgate et al. (1987). That system had no advantage over agar for quantitative study. Considerable effort was made to obtain a homogeneous experimental system but no acetylene reduction by $P$. putida(pMF250) or (pRD1) was detected in numerous assays in liquid glucose or pyruvate-NFDM shaken gently in air, stagnant in air or stagnant in sealed vessels at initial $\mathrm{pO}_{2}$ values ranging from 0.05 to $0.002 \mathrm{~atm}$.

\section{DISCUSSION}

This work provides unequivocal evidence of aerobic expression of the $K$. pneumoniae nif cluster in a taxonomically defined aerobic Pseudomonas background. It confirms the claims of Mergeay \& Gerits (1978) that nif from K. pneumoniae is expressed in the genus Pseudomonas and it indicates that there is no obstacle in principle to expression of this cluster in other aerobic physiological backgrounds. The extreme sensitivity of expression to $\mathrm{O}_{2}$-repression or inhibition suggests that ideal conditions for expression of nif from $K$. pneumoniae were not obtained in this work and implies that respiratory protection in these constructs is minimal. The apparent failure 
of constitutive $n t r C, n \operatorname{tr} A$ or nif $A$ plasmids to influence activity probably reflects this fact. The results also show that $P$. putida possesses a chromosomal ntr-like system sufficiently analogous to the $n \operatorname{tr} A$ ntrBC system of $K$. pneumoniae to activate $K$. pneumoniae nif and, further, that $x y l R$ is not involved.

\section{REFERENCES}

Barraquio, W. L., Padre, B. C., JR, Watanabe, I. \& KNowles, R. (1986). Nitrogen fixation by Pseudomonas saccharophila Doudoroff ATCC 15946. Journal of General Microbiology 132, 237-241.

Cannon, F. C. (1980). Genetic studies with diazotrophs. In Methods for Evaluating Biological Nitrogen Fixation, pp. 367-413. Edited by F. J. Bergersen. Chichester: John Wiley.

Cannon, F. \& Postgate, J. (1983). Expression of Klebsiella nitrogen fixation genes in Azotobacter - a caution. Nature, London 305, 390.

Cannon, F. C., Dixon, R. A., Postgate, J. R. \& Primrose, S. B. (1974). Chromosomal integration of Klebsiella nitrogen fixation genes in Escherichia coli. Journal of General Microbiology 80, 227239.

Davis, B. D. \& Mingioli, E. S. (1950). Mutants of Escherichia coli requiring methionine or vitamin B12. Journal of Bacteriology 60, 17-28.

Dixon, R. (1986). The $x y l A B C$ promoter from the Pseudomonas putida Tol plasmid is activated by nitrogen regulatory genes in Escherichia coli. Molecular and General Genetics 203, 129-136.

Dixon, R., Cannon, F. \& Kondorosi, A. (1976). Construction of a $\mathbf{P}$ plasmid carrying nitrogen fixation genes from Klebsiella pneumoniae. Nature, London 260, 268-271.

FigurSKi, D. H. \& HelinsKi, D. R. (1979). Replication of an origin-containing derivative of plasmid RK2 dependent on a plasmid function provided in trans. Proceedings of the National Academy of Sciences of the United States of America 76, 1648-1652.

KENNEDY, C. (1977). Linkage map of the nitrogen fixation (nif) genes in Klebsiella pneumoniae. Molecular and General Genetics 157, 199-204.

KenNEDY, C. K. \& Drummond, M. H. (1985). Use of cloned nif regulatory elements from Klebsiella pneumoniae to examine nif regulation in Azotobacter vinelandii. Journal of General Microbiology 131, 17871795.

KENNEDY, C. \& RoBson, R. L. (1983). Activation of nif gene expression in Azotobacter by the nif $A$ gene product of Klebsiella pneumoniae. Nature, London 301, 626-628.

Krishnapillai, V. \& Postgate, J. R. (1980). Expression of Klebsiella his and nif genes in Serratia marcescens, Erwinia herbicola and Proteus mirabilis. Archives of Microbiology 127, 115-118.

LEHTINEN, H. \& MÄNTSÄLÄ, P. (1981). Transfer of nitrogen fixation genes into Pseudomonas putida isolated from Finnish tundra soil. Antonie van Leeuwenhoek 47, 405-410.

MERgeay, M. \& Gerits, J. (1978). F'-plasmid transfer from Escherichia coli to Pseudomonas fluorescens. Journal of Bacteriology 135, 18-28.

Merrick, M., Filser, M., Dixon, R., Elmerich, C., Sibold, L. \& Houmard, J. (1980). The use of translocatable genetic elements to construct a finestructure map of the Klebsiella pneumoniae nitrogen fixation (nif) gene cluster. Journal of General Microbiology 117, 509-520.

Postgate, J. R. \& KeNT, H. M. (1985). Expression of Klebsiella pneumoniae nif genes in Proteus mirabilis. Archives of Microbiology 142, 289-294.

Postgate, J., Dixon, R., Hill, S. \& Kent, H. (1987). nif genes in alien backgrounds. Philosophical Transactions of the Royal Society of London B (in the Press).

Wheatcroft, R. \& Williams, P. A. (1981). Rapid methods for the study of both stable and unstable plasmids in Pseudomonas. Journal of General Microbiology 124, 433-437.

Williams, P. A. \& Worsey, M. J. (1976). Ubiquity of plasmids in coding for toluene and xylene metabolism in soil bacteria: evidence for the existence of new Tol plasmids. Journal of Bacteriology 125, 818828. 